\title{
Impact of Farmers/Herders Conflict on Food Security in Nigeria: A Case Study of Taraba State Nigeria
}

Oruonye, E. D*, Ahmed, Y. M, Fatima, A. Y

Department of Geography, Taraba State University, P.M.B. 1169 Jalingo, Taraba State, Nigeria

DOI: $10.36347 /$ sjahss.2020.v08i03.006

| Received: 03.03.2020 | Accepted: 10.03.2020 | Published: 30.03.2020

*Corresponding author: Oruonye, E. D

Abstract

Original Research Article

One of the greatest security challenges in Nigeria in recent time is the increasing conflicts between crop farmers and herders. Today, the conflict has spread over wide geographical areas on the continents of Africa, Nigeria and Taraba state in particular. In the same manner, the weapons used in the conflict have moved from small and light arms to use of heavy and complex weapons and ammunitions such as rifles and AK47 among others. Taraba State is one of the States in Nigeria that have been greatly affected by conflict between crop farmers and cattle herders. It is against this background that this paper examines the increased level of conflict between farmers and herders in Nigeria, the dynamics associated with the conflict and its impacts on food security in the country with special focus on Taraba State. This study analyses the factors that help cause or aggravate these conflicts, their evolution and spread, and their human toll in the State. It further assesses responses, especially by the federal government and its security agencies, and outlines possible strategies to reduce or prevent occurrence of the conflicts. The data for this study was drawn from both primary and secondary sources. Primary data was generated from field survey carried out in the State. The study utilised data and information from multiple policy documents (from the Federal and State Ministry of Agriculture and Livestock Service department) in Jalingo. Data generated from the survey was complemented by extensive desk review on the farmers-herders conflicts. Media tracking and records of farmers-herders conflicts provided additional sources of information. Key Informants Interview (KIs) was also employed to enrich the findings of the study. The findings of the study reveals that the increasing incidence of farmers-herders conflict is as a result of the breakdown of the traditional mechanism for resolving disputes and conflicts in rural communities. The increasing incidence of the farmers-herders conflicts has led to widespread destruction of lives and properties and entrenched an atmosphere of fear and insecurity in most rural communities. This has greatly affected both crop farming and grazing activities, resulting in low productivity. The study recommends the establishment of sustainable cattle ranching in different parts of the country and strengthening of State cooperation and fighting cross border movement of illicit arms and trafficking of drugs among others.

Keywords: Armed banditry, Farmers/herders conflict, Food security, Pastoral nomadism and Ranching.

Copyright @ 2020: This is an open-access article distributed under the terms of the Creative Commons Attribution license which permits unrestricted use, distribution, and reproduction in any medium for non-commercial use (NonCommercial, or CC-BY-NC) provided the original author and source are credited.

\section{INTRODUCTION}

Crop farmers and cattle herders have been known to live harmoniously over the years and have enjoyed mutual symbiotic relationship. This mutual symbiotic relationship has been very beneficial to the two groups. The cattle rearers have often paid to graze on farmlands after harvest or in exchange for cow milk or other dairy products while the cow droppings have often enriched the farmlands with manure. However, increasing human and animal population has led to shortage of cropland and grazing land, thereby resulting into competition over available land resources. These increased competitions over land have resulted in encroachment of farmlands into grazing reserves and cattle routes. The cattle rearers have often times intentionally or unintentionally allowed their cattle to graze on croplands, thereby destroying the crops before harvest. This development has brought about conflicts between the cattle herders and crop farmers. Many state governments in Nigeria have come up with anti-open grazing laws which made it illegal to practice nomadic grazing in these states. The Federal Government of Nigeria's attempt to implement RUGA policy which is aimed at settling the nomadic farmers met with stiff resistance by many State Governments and citizens leading to temporary suspension of the policy. 
This conflict which started gradually and often mediated by local community authorities has increasingly assumed a more complex dimension. The traditional conflict resolution mechanism that has helped resolve all forms of conflicts between crop farmers and cattle herders in the past has failed in recent times. This is mainly as a result of increasing distrust and suspicion among the two groups.

Today, the conflict has spread over wide geographical areas on the continents of Africa, Nigeria and Taraba state in particular. In the same manner, the weapons used in the conflict have moved from small and light arms to use of heavy and complex weapons and ammunitions such as rifles and AK47 among others.

Taraba State is one of the States in Nigeria that have been greatly affected by conflict between crop farmers and cattle herders. It has been observed that since 2012 to date, no week passes by without reported cases of conflicts between crop farmers and cattle rearers. Sadly enough, these conflicts always result into large scale destruction of lives and properties. This conflict in recent times has been complicated by incidence of cattle rustling and armed banditry. The cattle herders have acquired sophisticated arms as a means of defending themselves against cattle rustlers and armed bandits. They have also used these weapons to attack communities that attacked their cattle when they encroached on their farmlands. This has always led to reprisal attacks and counter attacks with monumental losses on both sides. These conflicts are, by every measure, complex and multidimensional. Formulating appropriate responses requires a clear diagnosis of their root causes, evolution, impacts and implications.

Today, there is trading of blames between the crop farmers and cattle herders. The crop farmers are accusing the cattle herders of allowing the cattle to destroy their farmlands without payment of compensation for the losses and damages done to their crops, while the cattle herders on the other hand accuse crop farmers of cultivating on their stock routes and grazing reserves meant for them. It is against this background that this paper examines the increased level of conflict between farmers and herders in Nigeria, the dynamics associated with the conflict and its impacts on food security in the country with special focus on Taraba State.

\section{METHODOLOGY \\ Description of Study Area}

Taraba state is found between latitude $6^{\circ} 25^{\prime} \mathrm{N}$ to $9^{\circ} 30^{\prime} \mathrm{N}$ and longitude $9^{\circ} 30^{\prime} \mathrm{E}$ to $11^{\circ} 45^{\prime} \mathrm{E}$. It has tropical continental type of climate. The State has land area of about $60,291 \mathrm{~km}^{2}$ with an estimated population of over 3 million people projected from the 2006 population census. The State is located on the mountain ranges in the Eastern borderland separating Nigeria and
Cameroon Republics. It is bordered on the west by Nassarawa and Plateau States, to the north by Bauchi and Gombe states and by Adamawa State to the northeast. It also shares its south western boundary with Benue State. Taraba State is bounded on the south and south east by the Republic of Cameroon (an international boundary). The State lies largely within the middle of Nigeria and consists of undulating landscape dotted with mountainous features.

The Mambilla Mountain region of the State provides a tsetsefly-free grassy highland area that is highly suitable for cattle rearing. It is one of the areas with the highest concentration of livestock population in Nigeria. It has been observed that over six million heads of cattle exist on the Mambilla plateau in the 1980s [1, 2]. The guinea and derived savanna zones provide much more adequate grazing during the dry season. In terms of their nutritive value they are at best only at the short period at the beginning of the rains when the plants are still young and succulent. As the rainy season progresses they grow coarser and provide less roughage. The luxuriant growth of the grasses also reduces the proportion of leguminous plants in the community which further lowers the nutritive value of the grasslands. The Sudan savanna part of the state with its tuft-forming grasses supports the largest population of livestock in the state. Unfortunately it also carries a great number of cultivators who compete for land with the pastoralists. This has resulted in the concentration of livestock in certain parts of the State, which automatically leads to overgrazing. The State has all breeds of animals including cattle, horse, donkeys, sheep, pigs, rabbits and poultry such as chickens, ducks, guinea fowls, doves, pigeons etc. Taraba state is a multi-ethnic society sharply divided along religion, ethnicity, culture and language; leading to different contexts of conflicts involving the Jukun, Tiv, Kuteb and Chamba [3].

\section{MATERIALS AND METHODS}

The data for this study was drawn from both primary and secondary sources. Primary data was generated from field survey carried out in the State. The study utilised data and information from multiple policy documents (from the Federal and State Ministry of Agriculture and Livestock Service department) in Jalingo. Interviews were conducted face to face with officials of the livestock service department and local livestock farmers. Discussions with local pastoralist were carried out in Hausa Language. Data generated from the survey was complemented by extensive desk review on the farmers-herders conflicts. The review provided understanding of the complex and dynamic nature of the problem. Media tracking and records of the farmers-herders conflicts provided additional sources of information. Key Informants Interview (KIs) was also employed to enrich the findings of the study. 


\section{Pastoral Nomadism}

Pastoral nomadism is the free movement of cattle rearers with their animals from place to place in search of pastures and water. Herd size ranges from 100 to 300 heads of indigenous breeds [4]. Nomadic pastoralism is a traditional way of life in which nomadic communities keep large numbers of animals moving from place to place in search of forage and water depending on where the rain falls [5]. Livestock production is subsistent in nature and animals are kept on uncultivated pastures and rely on grazing without any feed supplements. The main products include beef, milk, blood, hides, manure and horns. Thus, nomadic pastoralism is understood as a social and economic strategy predominantly based in routines (such as seasonal) migration and management of domesticated animals $[6,5]$.

Studies have shown that over 90 per cent of pastoralists are mainly Fulani. The Fulani are a large ethnic group spread across many West and Central African countries. They are believed to own about 90 per cent of the national herd, estimated at 19.5 million cattle, about 975,000 donkeys, 28,000 camels, 72.5 million goats and 41.3 million sheep [7]. Livestock makes up between 20 and 30 per cent of total agricultural production and about 6 to 8 per cent of overall Gross Domestic Production (GDP). About 30 per cent of live animals slaughtered in Nigeria are brought in by pastoralists from other countries.

Pastoral nomadism was considered very suitable in Northern Nigeria because of the relatively large expanse of communal land and pasture with very little population. Also the relatively drier nature of the environment which makes it unsuitable to cultivate most other type of crops on most of the land encouraged the free movement of animals in search of water and pasture. Over the years, there has been debate over the sustainability of nomadic grazing. Many scholars sees nomadic grazing as the most suitable way of using the fragile and relatively poor soil of the region since it distribute the effect of grazing over large area, thereby reducing the effect of degradation.

At the earliest time, the cattle herders have lived harmoniously with the crop farmers. They have had cordial and stable relationship that enables them to work side by side for decades. This interdependent relationship has enabled them to depend on each other for survival, and it formed the benchmark for exchange and which brought about even development [8]. The activities of the pastoralist include the movement of their cattle to graze on farmlands which belong to crop farmers, while the farmers require from the pastoralist protein in the form of dairy products that are needed for their day-to-day consumption and manure to fertilize their fields [8].
However, the Fulani cattle rearers have over the years increased their stock of animals. Traditionally, the animals are raised not for fattening and sale but rather they are raised to increase their stock of herds which they see as symbol of affluence and position in the community. This increase in stock of herds and increasing dryness of the environment led to degradation of most parts of Northern Nigeria. This is further made worst by increasing desertification in the north, thereby forcing the Fulani cattle rearers to move southward.

The southward movement to the wetter Middle belt region with increasing population of crop farmers has brought about constant clashes between the two groups. Although, before now, cattle rearers and crop farmers have their traditional ways of settling disputes among themselves, this mechanism has failed in recent times and the conflict is assuming a very dangerous and devastating dimension which involves not only the use of small and light weapons but complex and sophisticated arms. There has been increasing frequency of these farmers-herders conflicts in recent times particularly from 2017 to date leading to total burning down of whole communities with grave impacts. This development has created an atmosphere of fear and insecurity in most rural communities in Nigeria particularly in Taraba, Benue, Adamawa, Nassarawa, Kaduna and Plateau states. This development has made farmers-herders conflicts to be a front burner issue of discourse in Nigerian security challenges in recent times and calls to question the sustainability of nomadic grazing. Thus, both government and citizens are working to come up with practicable alternatives to nomadic grazing that will entrench lasting peace and security in the country.

\section{Importance of Livestock}

Goldschmidt correctly points out the fact that livestock, particularly cattle, are not merely a food resource only, but rather, they are also capital, which is essential to all kinds of negotiations involving influence and alliance; they are not merely savings, they are the only form of investment available to tribal pastoralists [9]. Cattle are the single most important livestock species in Nigeria, in terms of animal protein supply, value and biomass. They provide not only meat and milk, but also skin, bone, blood and horn products, and are used to transport people and loads, to pull ploughs, carts and ridgers, and to lift water from deep wells. Cattle are found throughout Nigeria, but are most common in the northern two thirds of the country. Almost half the total cattle population is permanently resident within the sub-humid zone [10]. Thus, the importance of livestock includes;
i. Sources of food
ii. Source of livelihood
iii. Source of income
iv. Source of employment opportunity
v. Means of transport 


$\begin{array}{ll}\text { vi. } & \text { Draft power } \\ \text { vii. } & \text { Source of manure } \\ \text { viii. } & \text { Source of savings and insurance } \\ \text { ix. } & \text { Source of social status } \\ \text { x. } & \text { Source of wealth reserve } \\ \text { xi. } & \text { Source of sacrificial gift } \\ \text { xii. } & \text { Means of marriage and other ceremonial } \\ & \text { payments (Salih, 1992). }\end{array}$

\section{Grazing Reserve}

Grazing reserves in Nigeria are areas set aside for the use of pastoralists and are intended to be the foci of livestock development [11]. A grazing reserve as the term implies, are areas of land demarcated, set aside and reserved for exclusive or semi-exclusive use by pastoralists [12]. Grazing reserves resemble group ranches in that both consist of clearly defined areas of rangeland which provides grazing for determined herds of livestock [13].

The establishment of grazing reserve started during the colonial era down to the post-colonial era as measures to sedentarize the nomadic cattle rearers, reduce conflicts, provide access to improved fodder and social facilities, improved animal health and husbandry practices, active participation of the pastoralists in the national economy, wealth creation and increased incomes amongst others [12]. The grazing reserves were developed out of forest reserves, which were set up in the colonial era, and were intended to conserve woodland resources. Large expanses of land were earmarked as grazing reserves. Some of them were backed up by law officially gazetted and provided with infrastructure such as dams and boreholes while others were not gazetted [11]. The establishment of grazing reserve serve as incentive to get the nomadic cattle rearers to settle down through the provision of land for grazing and permanent water [14]. In those days, grazing grounds were allocated to pastoralists around towns and villages for use particularly during the farming season. However, since there was no legal instrument to prevent encroachment by crop farmers, such reserved areas subsequently disappeared with increasing population and cropping intensity [11]. The Nigerian Government's Grazing Reserve Act of 1964 was a response to the problem of alienation of grazing lands increasingly being faced by the pastoral population at that time. In a broader perspective, the law was enacted as one of the policy measures to address some of the challenges facing livestock development in Nigeria [11].

In 1976, the government of Northern Nigeria passed the grazing law, primarily to encourage the settlement of herdsmen for several reasons, including addressing their lack of land rights, reducing or limiting movement of herds (which limits access to health facilities and improves the management of the herds), facilitating the adoption of a modernized approach to cattle rearing, and the institution of a ranching system [15].

By 19802.3 million ha were acquired as grazing reserves by the northern state governments [16], constituting $10 \%$ of the total 22 million ha envisaged under the Third National Plan [17, 11]. Less than 20 of those grazing reserves were provided with some basic infrastructure. There are presently 417 grazing reserves (2.8 million hectares) that have failed in terms of the objectives for which they were established [18]. Only 177 out of this number had been gazetted and the Federal Government is working on converting them into ranches [19].

The old Gongola State which comprised of present day Adamawa and Taraba States had 72 proposed reserves ( 52 reserves were to be controlled by the state government and the remaining 20 by the local government). The establishment of such functional reserves was expected to encourage the sedentarization of nomads, and provide the framework for addressing some of the major challenges of pastoralists, such as access to education and improved livestock productivity through efficient veterinary services.

Thus, grazing reserves were established not only to protect grazing lands from crop farming and provide easier access to them by pastoralists but also to encourage the sedenterization of nomadic/transhumant pastoralists through legally secure titles to grazing land and water and, in general, as one means of promoting livestock development [11].

Since their establishment by the colonial state and sustenance by post-independent governments, grazing reserves were additionally provisioned with supporting facilities such as feeder roads, earth dams, boreholes, veterinary and health clinics, bush fire protection, milk marketing facilities, improved pasture, etc [12].

There are nine (9) grazing reserves in Taraba State occupying an area of $279 \mathrm{~km}^{2}$ as shown in Table-1. The Table shows that only 5 out of the 9 grazing reserves have been gazetted. The Table also shows that only 3 out of the 9 grazing reserves have some facilities in it. All the grazing reserves in the state have been encroached upon. The neglect of the grazing reserves and the lack of protection of their boundaries, led to high level of encroachment of farming activities. 
Table-1: Gazetted Grazing Reserves in Taraba State

\begin{tabular}{|c|c|c|c|c|c|c|c|c|}
\hline $\mathbf{S} / \mathbf{N}$ & Grazing & Location & Size & \multicolumn{4}{|c|}{ Present Status } & \multirow{2}{*}{$\begin{array}{l}\text { Level of } \\
\text { development }\end{array}$} \\
\hline A & $\begin{array}{l}\text { Gazetted } \\
\text { Reserve }\end{array}$ & & & Surveyed & Demarcated & Gazetted & $\begin{array}{l}\text { Gazette } \\
\text { Notice }\end{array}$ & \\
\hline 1 & Didango & $\mathrm{K} /$ Lamido & $15 \mathrm{~km}^{2}$ & $\sqrt{ }$ & $\sqrt{ }$ & $\sqrt{ }$ & $\begin{array}{l}\text { No.1 Vol. } \\
13,1987\end{array}$ & - \\
\hline 2 & & Zing & $12 \mathrm{~km}^{2}$ & $\sqrt{ }$ & $\sqrt{ }$ & $\sqrt{ }$ & - & 1 borehole \\
\hline 3 & $\begin{array}{l}\text { Gankwe- } \\
\text { Assen }\end{array}$ & Donga & $115 \mathrm{~km}^{2}$ & $\sqrt{ }$ & $\sqrt{ }$ & $\sqrt{ }$ & $\begin{array}{l}\text { No.37 Vol. } \\
\text { II, } 1986\end{array}$ & - \\
\hline 4 & Mayo Kam & Bali & $45 \mathrm{~km}^{2}$ & $\sqrt{ }$ & $\sqrt{ }$ & $\sqrt{ }$ & $\begin{array}{l}\text { No.33 Vol. } \\
8,1998\end{array}$ & $\begin{array}{l}1 \text { Earth dam, } 5 \\
\text { boreholes }\end{array}$ \\
\hline 5 & Jibu & Wukari & $15 \mathrm{~km}^{2}$ & $\sqrt{ }$ & $\sqrt{ }$ & $\sqrt{ }$ & - & - \\
\hline 6 & Sunkani & A/Kola & $21 \mathrm{~km}^{2}$ & $\sqrt{ }$ & $\sqrt{ }$ & $\sqrt{ }$ & $\begin{array}{l}\text { No.9 Vol. } \\
\text { II, } 1986\end{array}$ & $\begin{array}{l}2 \text { boreholes, } 1 \\
\text { Nom. sch }\end{array}$ \\
\hline 7 & Mallum & A/Kola & $26 \mathrm{~km}^{2}$ & $\sqrt{ }$ & $\sqrt{ }$ & $\sqrt{ }$ & - & - \\
\hline 8 & Kirim & K/Lamido & $16 \mathrm{~km}^{2}$ & $\sqrt{ }$ & $\sqrt{ }$ & $\sqrt{ }$ & $\begin{array}{l}\text { No.3 Vol. } \\
13,1987\end{array}$ & - \\
\hline 9 & Yonko & Zing & $14 \mathrm{~km}^{2}$ & $\sqrt{ }$ & $\sqrt{ }$ & $\sqrt{ }$ & - & - \\
\hline
\end{tabular}

Source: Min. of Agric. (Livestock Service dept.) State, Jalingo

The establishment of grazing reserves by the provisions of the Federal Land Act of 1978 involves high compensation for acquisition of land. This is a major reason for the low implementation in establishing grazing reserves. The other reason is the fact that only few of those established were formally gazetted leaving the original objectives largely unfulfilled [20]. In some specific cases, none of the pastoral Fulani households settled on the reserves were previously nomadic having been residents around the crop farming villages prior to the establishment of the grazing reserves [21].

The local communities and grazing reserves were connected with well-established grazing routes through which animals go to eat fresh grass and drink water across the country since colonial time. However, over the years, local farmers and politicians turned many grazing areas into farmlands thereby blocking the herders access to the grazing fields [19]. The encroachment of the grazing reserves has blocked the traditional cattle migration routes, thereby bringing conflict between crop farmers and cattle herders.

\section{Grazing Routes}

Grazing routes have been established long ago to help order the movement of livestock from one state, region or part of the country to another. Taraba State has 4 major International and 8 national stock routes which runs across the State as shown in Fig-1. The routes are utilized by nomadic cattle rearers during their seasonal movements and also during daily grazing activities by sedentary pastoralist within the State. The major stock routes of the State are as follows:

i. Karim Lamido - Jebjeb (Plateau State)

ii. Karim Lamido - Lamurde - Bachama (Adamawa State)

iii. $\quad$ Karim Lamido - Tingou - Lafiya - Kiri (Adamawa State)

iv. Dorofi - Gembu - Nguroje (Taraba State)

v. Nguroje - Maisamari - Abong - Takum (Taraba State)

vi. Takum - Katsina Ala - (Benue State)

vii. Jalingo - Chidiya - Wukari (Benue State)

viii. Wukari - Akwana (Benue State)

The international stock routes are shown in Table-2.

Table-2: International Stock Routes (through Taraba State)

\begin{tabular}{|l|l|l|l|}
\hline S/N & Name of Stock & LGA & Distance \\
\hline 1 & Kuzang to Dogon Gawa & Yaro, Jalingo, Ardo Kola, Bali, Donga, Ussa and Takum & $325 \mathrm{kms}$ \\
\hline 2 & Njawaito Sabongida & Sardauna, Donga, Karim Lamido & $325 \mathrm{kms}$ \\
\hline 3 & Dorofi to Nguroje & Sardauna & $112 \mathrm{kms}$ \\
\hline 4 & Kossa to River Benue & Kossa & $140 \mathrm{kms}$ \\
\hline
\end{tabular}

Source: Min. of Agric. Jalingo 


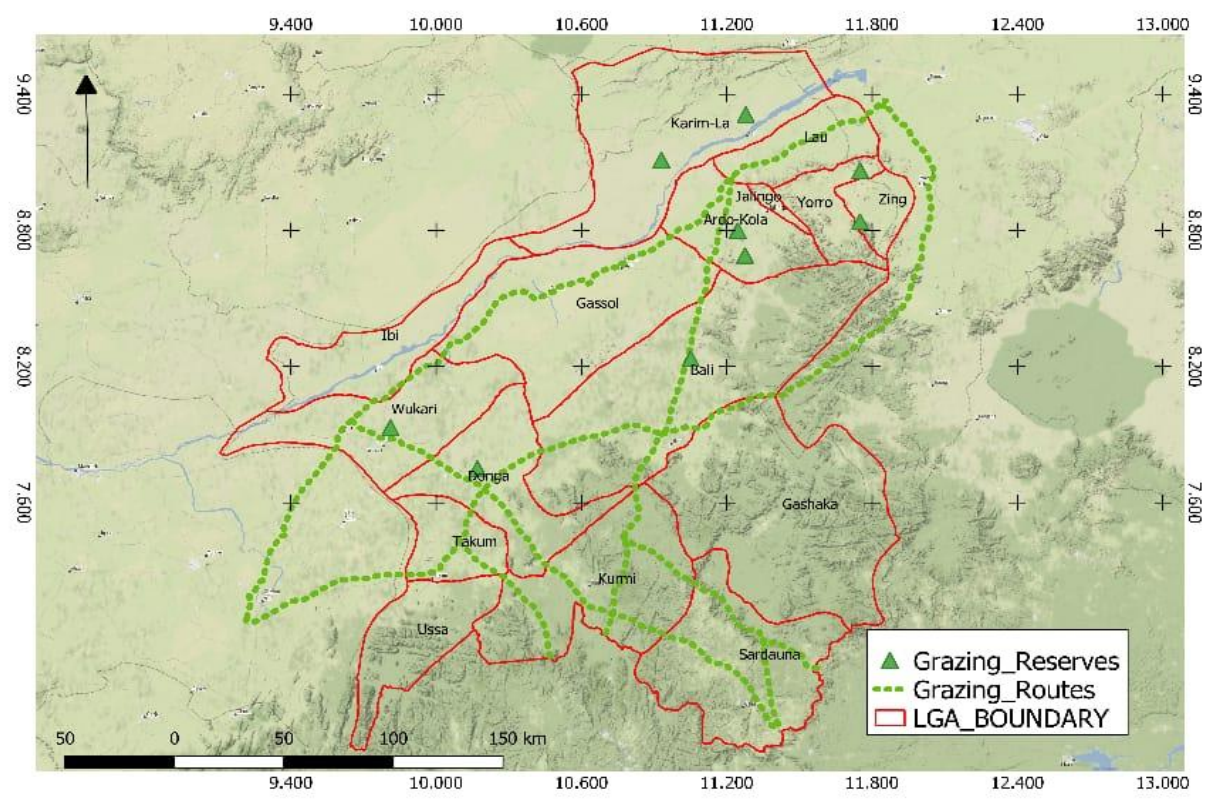

Fig-1: Map of Taraba State showing grazing routes Source: National Livestock Project Division Dec. 2002.

The State regional routes are not different from either of the local and national routes since the network of the local routes in the State transcends LGA boundaries and link grazing areas in different Local Government Areas and villages. There are also a network of local routes that lead to grazing areas and watering points in the State. The local routes transcend Local Government boundaries. The path of the main local routes documented by the Livestock Production and Nomadic Settlement division in the State are much to be listed here.

\section{Ranching}

Ranching is a long existing agricultural practice that involves raising of livestock, which commonly includes grazing animals such as cattle and sheep, on designated land structures. Usually in many countries, a ranch would be an open space secured with a fence made from strong wood. Ranching facilitates creation of employment opportunities as it develops the livestock value chain. Animals reared in a ranch are also protected from predators and do not intrude other farmer's properties. Hence, ranching is a highly recommended farming practice.

Although this system has the disadvantage of movement restrictions, it is beneficial in that it enhances land use by making use of marginal or range areas that cannot support any meaningful crop farming. It is a controlled system that enables the production of healthier animals and better products. With the quality of product from ranching, foreign exchange can be generated through the sale of livestock products. Moreso, ranching business which was suggested by the government of Nigeria in the previous year required building them near populated areas. These are areas that prevent livestock expansion, making it difficult for ranchers to increase breeder stock.

However, ranching has its own disadvantage which is why it has not been a well applicable method of livestock production in Nigeria. Ranching is a capital intensive venture that requires a lot of money to build. It requires the construction of fences, grain stores, feedlots, and watering places among others. This is why many cattle-herders are not willing to venture into ranch establishment. Also some herdsmen perceive ranching schemes to be an obstruction of freedom and as a forceful imposition by technicians and livestock assistants that are not exactly in the livestock business.

\section{RESULT OF THE FINDINGS \\ Farmers - Herders Conflicts}

Farmers-herders conflicts can be describe as a situation where animals eat up fresh crops from the farms and the farmer tries to retaliate leading to violence. The degree of conflict between different resource users ranges from insignificant to extremely tense conflict. Blench (2004) observe that conflict between pastoralists and farmers far outweighs all other types of resource conflict in frequency and importance. Taraba state is one of the states in the country that has been most affected by the farmers-herders conflicts as shown in Table-2. The Table- 2 reveals that there are 363 communities and 16,776 livestock that were affected by the farmers and herders conflicts in the State. The increasing population, expansion of crop farmlands, encroachment of grazing reserves and decline in pastures have brought about conflicts between crop farmers and cattle herders. These conflicts have been very much politicised in recent times, thereby making the conflict to assume a very dangerous religious and ethnic dimensions. This is understandable when one consider that about 90 per cent of the cattle 
herders are mostly the traditional nomadic Muslim Fulani while majority of the crop farmers are mostly Christians from different ethnic groups. It is believed that the farmer-herder conflict killed six times more people than the Boko Haram insurgency war in the first half of 2018. The frequency, destruction and fatalities associated with farmers and herders conflict is becoming very alarming and calls for urgent attention. The conflict which in the past was very common in the North and North-central geopolitical zone has spread to the western and core Southern part of the country [22]. Sadly enough, the statistics about the killings of Fulani and their cattle are hardly reported by the Nigeria media [23]. There is great under and unbalanced reporting of the conflict between the Fulani herdsmen and farmers over the years.
One will appreciate the complexity of the problem by looking at the key actors. They main visible actors are the Fulani and young men who tend the cattle while the real owners are the capitalists and economic elites who own the cattle and live in the big cities [24]. Several studies [25-27] have documented the usage of hired herders by wealthy Fulani of high echelon in the Middle Belt of Nigeria [5]. Also, the increasing political control of Local Government Councils by representatives of farming populations has meant pressure both to invade land reserved for grazing and to exclude pastoralists from high-productivity areas. As a consequence, there are much higher levels of resource conflict, with marked increases in violence between seasonal migrant herders and resident farming populations [28].

Table-2: Communities affected by farmers/herders conflicts in Taraba State

\begin{tabular}{|c|c|c|c|c|c|c|c|c|c|}
\hline \multirow[t]{2}{*}{$\mathbf{S} / \mathbf{N}$} & \multirow[t]{2}{*}{ LGA } & \multirow{2}{*}{$\begin{array}{l}\text { No. of Communities } \\
\text { affected }\end{array}$} & \multirow{2}{*}{$\begin{array}{l}\text { No. of Livestock } \\
\text { farmers }\end{array}$} & \multicolumn{6}{|c|}{ Types of Animal Lost } \\
\hline & & & & Cattle & Sheep & Goats & Poultry & Pigs & Horse \\
\hline 1 & Ardo Kola & 12 & 355 & 224 & 340 & 623 & 1,720 & 15 & - \\
\hline 2 & Didding Bali & 39 & 451 & 612 & 2,256 & 3,252 & 3,588 & 1,776 & - \\
\hline 3 & Donga & 12 & 126 & 525 & 436 & 950 & 2,861 & 159 & - \\
\hline 4 & Gashaka & 08 & 86 & 339 & 221 & 522 & 1,620 & 63 & - \\
\hline 5 & Gassol & 52 & 179 & 541 & 45 & 27 & 340 & - & - \\
\hline 6 & Ibi & 05 & 24 & 321 & 653 & 428 & 786 & 36 & - \\
\hline 7 & Jalingo & 04 & 82 & 332 & 260 & 265 & 2,786 & 130 & - \\
\hline 8 & K/Lamido & 05 & 150 & 432 & 121 & 986 & 1,720 & 35 & - \\
\hline 9 & Kurmi & 06 & 15 & 1,300 & 647 & 596 & 1,629 & 347 & 03 \\
\hline 10 & $\mathrm{Lau}$ & 26 & 3,900 & 10,400 & 12,597 & 10,634 & 7,800 & 386 & 08 \\
\hline 11 & Sardauna & 85 & 2,782 & 57,075 & 8,415 & 239 & 2,560 & - & 309 \\
\hline 12 & Takum & 07 & 2,321 & 1,240 & 3,986 & 939 & 4,263 & 296 & - \\
\hline 13 & Ussa & 08 & 2,601 & 580 & 2,996 & 3,490 & 5,621 & 130 & - \\
\hline 14 & Wukari & 73 & 2,692 & 1,726 & 4,692 & 3,239 & 6,269 & 4,567 & - \\
\hline 15 & Yorro & 07 & 628 & 820 & 229 & 1,635 & 3,271 & 120 & - \\
\hline 16 & Zing & 09 & 288 & 632 & 432 & 1,259 & 2,120 & 854 & - \\
\hline \multirow[t]{2}{*}{17} & $\begin{array}{l}\text { Nyangtu } \\
\text { Dev }\end{array}$ & 05 & 96 & 236 & 189 & 349 & 1,228 & 57 & - \\
\hline & Total & 363 & 16,776 & 77,335 & 38,515 & 29,433 & 50,182 & 8,971 & 320 \\
\hline
\end{tabular}

In 2013, about 3,000 Fulani herdsmen were displaced by the spate of clashes between Fulani herdsmen and several 'indigenous' communities in Taraba State, where about 500 herdsmen were reportedly killed and about 23,000 were forced to move into the Cameroon Republic Daily Independent, March 14, 2014 cited in Egwu [10]. The outbreak of conflicts between farmers and herders in 2019 has resulted in the displacement of over 70,600 persons in Taraba State as shown in Table-3.

Table-3: Number of IDPs from Farmers and Herders Conflicts in Taraba State

\begin{tabular}{|l|l|l|}
\hline S/No & Affected LGAs & No. of IDPs \\
\hline 1 & Ardo Kola & 5,780 \\
\hline 2 & Bali & 8,500 \\
\hline 3 & Jalingo & 24,807 \\
\hline 4 & Karim Lamido & 8,600 \\
\hline 5 & Lau & 20,595 \\
\hline 6 & Yorro & 2,340 \\
\hline 7 & Total & 70,622 \\
\hline \multicolumn{2}{|c|}{ Source: TSEMA, 2020 }
\end{tabular}

It has been observed that reprisal attacks more often are not directed at the actual communities where the initial attacks come from, rather, they are directed at communities known or believed to have sympathy for the communities from which the first attack comes from [24]. When reprisals are to be carried out, such acts are visited on communities proximate or known allies of opposing communities. In this way, several communities have been destroyed and members of those communities displaced as seen in Table- 3 .

\section{Causes of Farmer Herders Conflicts}

The International Crisis Group Report [29] reported that the desert frontline states like Bauchi, Borno, Gombe, Jigawa, Kano, Katsina, Kebbi, Sokoto, Yobe and Zamfara were experiencing southward movement of the deserts land with 50-75 per cent of the land area drying up progressively. This led to the continuous decline in the available pasture. This development has increased the southward movement of the cattle herders. Crisis Group [29] reported that some 
herders have chosen to graze their herds permanently in the Central and South zone of Nigeria. This compelling movement has led to the massive influx of herders in the south, thereby resulting into increase in violent clashes between herdsmen and residents of the community where they migrate to especially the farmers [30].

Some scholars have argued that the search for pastures by the nomadic pastoralists constitutes an encroachment on the farmers' farmland, without due compensation when the property is destroyed [5]. Also, expansion of farms and settlements that resulted into encroachment and taking over of grazing reserves in the State and country contributes to the conflict.

Rapid growth of ethnic militias across different parts of the country - the hired herdsmen who are most heavily armed do not hesitate to release fire on their aggressors with the ripple effect leading to the death of high numbers of victims and mass displacement of the affected persons or communities in Nigeria. To further prevent the herdsmen from persistent encroachment, the aggrieved farmers tend to form themselves into groups to attack the cattle. In most cases, they adopt the use of traps which kills the cattle, thus, leading to aggression between the hired herdsmen and farmers [5].

There has been evidence of community heads encouraging farmers to build vigilante networks who are empowered with local weapons to guard their territory and farmlands that are continually encroached upon by the Fulani herdsmen due to the growing demands of pastures for their cattle [22]. Unfortunately, in carrying out the responsibility of providing pasture by the herdsmen for their livestock, they do adopt guerrilla warfare approach by invading farmlands of farmers [5].

The problem now is with increasing conflict, the farmer now seeks to protect their farmland, and herdsmen adopt violent mechanisms in safeguarding their cattle during grazing [31]. This has led to the proliferation of small arms and carrying of illegal weapons during grazing activities by the pastoralist in the name of self-defence against the systemic attack of cattle rustler during grazing which has led to the death of Fulani herdsmen and their cattle [32]. However, the situation worsens as both groups continue to cause havoc to the community, endangering the lives of people [31].

Some scholars have argued that the farmersherders conflicts are rooted in climate-induced degradation of pasture and increasing incidence of cattle rustling in the country. Other causes of the conflicts in the State include the inability of Federal Government to prosecute past perpetrators or respond to early warnings of impending attacks and introduction of different anti-grazing laws in some States in Nigeria including Taraba State.

\section{Effects of Farmers - Herders Conflicts}

The farmers and herders conflicts have resulted to insecurity in many parts of the country, particularly Adamawa, Benue, Nasarawa, Plateau and Taraba states. The conflicts has scared investors and impeded government efforts in addressing the economic and cultural challenges of development in the area. It also rendered many people destitute. Markets were burnt, residential buildings, schools, financial and health institutions, as well as farmlands were destroyed. The incessant conflict between farmers and herders is costing the country, especially the north-central region huge revenue loss, as much as at least $\$ 14$ billion in potential revenues annually according to Mercy Corp report [33].

The farmers and herders conflicts have also resulted into large scale displacement of people from their native homes. This has constituted hindrance to crop farming and cattle herding activities in the state, resulting to rising food prices in some instances. The conflict has also led to loss of lives and properties, i.e. about 3,641 people have lost their lives in the past three years across different states of the federation. The conflicts have therefore constituted heavy burdens on security operatives in the country who continue to grapple with daily security challenges across the country.

\section{Federal Government Response}

The International Crisis Group [29] which compiled a very elaborate report on the farmer-herder conflicts in Nigeria has revealed that the Nigerian government's response to farmers and herders conflict ranges between deployment of military operations and mediation by persons with reputation at a crisis point. When military forces are deployed to contain conflict incident, the treatment of the civil population has itself become a critical political and security challenge [34]. The accounts of the excessive use of force, extrajudicial killings and other human rights abuses associated with military engagement cannot be overemphasized. The government also sent it officials on consolation visits to the affected communities and pay compensations for damages by the cattle herders or local/state government depending on the severity of damages done by the cattle. The Nigerian government also responded by initiating a 10-year National Livestock Transformation Plan (NLTP) as part of efforts to address clashes between herdsmen and farmers [35]. The plan, according to government, is expected to gulp about N91billion in investments, while a profit of N2trillion is expected over the 10-year period. Taraba State government also proposes to establish 3 ranches (one in each senatorial district) in 2017 as shown in Table-4 and later discontinue with the idea. Other response by the government includes a 
proposed bill to establish a Federal Commission to cater for and manage transhumant stock routes and Grazing Reserve Areas. The bill is still pending before the
National Assembly. All these efforts have failed as clashes between the two groups continue unabated.

Table-4: Taraba State Proposed Pilot Ranches (2017)

\begin{tabular}{|l|l|l|l|l|l|l|}
\hline S/N & Zone & LGA & Town & $\begin{array}{l}\text { Nearest } \\
\text { village }\end{array}$ & Size & $\begin{array}{l}\text { Year of proposed } \\
\text { establishment }\end{array}$ \\
\hline 1 & $\begin{array}{l}\text { Northern } \\
\text { Senatorial zone }\end{array}$ & $\begin{array}{l}\text { Ardo } \\
\text { Kola }\end{array}$ & Sunkani & Dibo & $21 \mathrm{~km} 2$ & 2017 \\
\hline 2 & $\begin{array}{l}\text { Central Senatorial } \\
\text { zone }\end{array}$ & Bali & Mayo Kam & $\begin{array}{l}\text { Vicbalkom } \\
\text { farm }\end{array}$ & $45 \mathrm{~km} 2$ & 2017 \\
\hline 3 & $\begin{array}{l}\text { Southern } \\
\text { Senatorial zone }\end{array}$ & Donga & $\begin{array}{l}\text { Gankwe } \\
\text { Hassel }\end{array}$ & Annanum & $115 \mathrm{~km} 2$ & 2017 \\
\hline
\end{tabular}

Source: Field Interview, 2020.

\section{CONCLUSION}

This study has investigated the impact of farmers-herders conflicts on food security in Nigeria using the case of Taraba State. The study findings reveal that there are 363 communities and 16,776 livestock that were affected by the farmers and herders conflicts in the State. The increasing population, expansion of crop farmlands, encroachment of grazing reserves and decline in pastures have brought about conflicts between crop farmers and cattle herders. These conflicts have been very much politicised in recent times, thereby making the conflict to assume a very dangerous religious and ethnic dimensions. The findings of the study reveals that the farmers-herders conflict has persisted over the years as a result of the breakdown of traditional mechanism for resolving disputes and conflicts in rural communities. The increasing incidence of the farmers-herders conflicts has led to widespread destruction of lives and properties and entrenched an atmosphere of fear and insecurity in most rural communities. This has greatly affected both crop farming and grazing activities, resulting in low agricultural productivity. While the government and people continue to search for lasting solution to the problem of farmers and herders conflicts, time is of essence given the enormity of the destruction associated it.

\section{RECOMMENDATION}

Based on the findings of the study, the following recommendations were suggested;

- Establishment of sustainable cattle ranching in different parts of the country.

- Strengthening of State cooperation and fighting cross border movement of illicit arms and trafficking of drugs.

\section{REFERENCE}

1. Frantz SW, Sinsheimer JE. Bacterial mutagenicity and toxicity of cycloaliphatic epoxides. 1981.

2. Tukur HA. Revenue Mobilization and Allocation in Nigeria: Performance and Prospects. 2005.

3. Adamu A, Ben A. Migration and violent conflict in divided societies: Non-Boko Haram violence against christians in the middle belt region of Nigeria. Nigeria Conflict Security Analysis Network (NCSAN) Working Paper No. 1,World Watch Research. 2015.

4. Momale SB. Changing Methods of Animal Husbandry, Cattle Rustling and Rural Banditry in Nigeria. In In Mohammed J. Kuna and Jubrin Ibrahim (Eds.) Rural Banditry and Conflicts in Northern Nigeria. Centre of Democracy and Development, Abuja, Nigeria. 2015.

5. Aljazeera. Amnesty: Farmer-herder clashes kill 3,600 in Nigeria. Online News, 17th December, 2018.

https://www.aljazeera.com/news/2018/12/amnesty -farmer-herder- clashes-kill- 3600-nigeria181217101114812.html

6. Khazanov AM. Nomads and the outside world. University of Wisconsin Press; 1994.

7. Eniola MS, Adebiyi K. Emotional intelligence and goal setting - an investigation into interventions to increase motivation to work among visually impaired students in Nigeria. British Journal of Visual Impairment. 2007 Sep;25(3):249-53.

8. Shettima AG, Tar UA. Farmer-pastoralist conflict in West Africa: exploring the causes and consequences. Information, Society and Justice Journal, 2008;1(2):163-184.

9. Galaty J, Aronson D, Salzman PC. (eds). The Future of Pastoral Peoples. Nairobi: IDRC. 1980.

10. Egwu S. The Political Economy of Rural Banditry in Contemporary Nigeria. In Mohammed J. Kuna and Jubrin Ibrahim (Eds.) Rural Banditry and Conflicts in Northern Nigeria. Centre of Democracy and Development, Abuja, Nigeria. 2015.

11. Ingawa SA, Tarawali C, Von Kaufmann R. Grazing reserves in Nigeria: Problems, prospects and policy implications. African Livestock Policy Analysis Network (ALPAN) Network Paper No. 22 December 1989.

12. Muhammad-Baba TA, Mohammed BT. The State of Grazing Reserves and Their Potential Capacity to Absorb Pastoralists. In In Mohammed J. Kuna and Jubrin Ibrahim (Eds.) Rural Banditry and Conflicts in Northern Nigeria. Centre of 
Democracy and Development, Abuja, Nigeria. 2015.

13. Oxby C. Group Ranches in Africa. Pastoral Network Paper 13d. Overseas Development Institute, London. 1982.

14. Suleiman H. Development of Grazing Reserves and Settlement of Pastoralists. Paper Presented at the Seminar on Second National Livestock Development Projects held at a Durbar Hotel, Kaduna, Nigeria from 9th to 10th December, 1986.

15. Awogbade MO. Grazing reserves in Nigeria. Nomadic Peoples. 1987 Jan 1:19-30.

16. Oxby C. Progress in the Settlement of the Nomadic Herds in the Sub Humid Savannahs of Africa. Report prepared for FAO under the Programme for the Control of African Animal Trypanosomiasis and Related Development. ODI, London. 1982.

17. Ontario. Ministry of Agriculture, Food. Economics, Policy Coordination Branch. Statistics, Surveys Section, Ontario. Department of Agriculture. Statistics, Publications Branch, Ontario. Farm Economics, Statistics Branch. Statistics Division, Ontario. Department of Agriculture. Statistics Section, Ontario. Ministry of Agriculture, Food. Policy Analysis Branch. Statistical Services Unit. Agricultural statistics for Ontario. Statistics and Publications Branch, Ontario Department of Agriculture; 1981.

18. Ma Y, Tukur A, Kelly Kissock PhD PE. Energyefficient static pressure reset in VAV systems. ASHRAE Transactions. 2015;121:102.

19. Saturday Punch. FG to convert 177 grazing reserves for use. Online News. July, 14, 2018. https://punchng.com/ranching-fg-to-convert-177grazing-reserves-for-use/

20. Waters-Bayer A, Taylor-Powell E. Settlement and Land use by Fulani Pastoralists in case study areas. In: Kaufmann R von, Chater S. and Blench R. (eds). 1986.

21. Kjenstad V. Land Tenure in the Sub humid Zone of Nigeria, Implications for Agricultural Iinnovations: A literature review. Report to ILCA, Ibadan. 1988.

22. Aluko O, Gowtham S, Odegard GM. Multiscale modeling and analysis of graphene nanoplatelet/carbon fiber/epoxy hybrid composite. Composites Part B: Engineering. 2017 Dec 15;131:82-90.

23. Abubakar IR, Dano UL. Socioeconomic challenges and opportunities of urbanization in Nigeria. In Urbanization and Its Impact on Socio-
Economic Growth in Developing Regions (pp. 219-240). IGI Global. 2018.

24. Institute for Peace and Conflict Resolution (IPCR). 2016 Strategic Conflict Assessment of Nigeria Consolidated and Zonal Reports. Institute for Peace and Conflict Resolution, Abuja. 2017.

25. Blench R. Pastoral labour and stock alienation in the sub humid and arid zones of West Africa. 1985.

26. BonfigliolI AM. Evolution de la propriete animale chez les Wodaa6e du Niger. Journal des Africanistes LV, 1985; (1-2):29-37.

27. Turner BS. Regulating bodies: Essays in medical sociology. Psychology Press; 1992.

28. Blench R. The history and spread of donkeys in Africa. Wageningen: ACP-EU Tecnical Center for Agriculture and Rural Cooperation. 2004.

29. International Crisis Group. Mafia of the poor: Gang violence and extortion in Central America. Latin America \& Caribbean, Report No. 62. 2017 Apr 6.

30. Isola O. Herdsmen and Farmers Conflict in Nigeria: A threat to Peacebuilding and Human Security in West Africa. Woodrow Wilson International Center for Scholars. 2018.

31. Genyi GA. Ethnic and religious identities shaping contestation for land based resources: The Tiv farmers and pastoralists conflicts in central Nigeria. 2014. Retrieved on August 23, 2016 from http://www.icermediation.org/news-

media/meeting-coverage/ethnic-and-r eligiousidentities-shaping-contestation-for-land-basedresources-the-tiv-farmers-and-pastoralistconflictsin-central-nigeria/

32. Marietu ET, Olarewaju OI. Resource conflict among farmers and Fulani herds men: Implications for resource sustainability. African Journal of Political Science and International Relations. 2009 Sep 1;3(9):360.

33. Agbedo O. Tracking endless Fulani herdsmen/farmers clashes. The Sun, 2016; 27 December, available at: (accessed 04 September 2016).

34. Hoffman RF, Rand MR. Instrumental enrichment, an intervention program for structural cognitive modifiability: Theory and practice. Think. Learn. Skills. 2014 Jun 3;1:43.

35. Sahara Reporters. Nigerian Government Approves N91billion For Grazing Reserves, New York Jan 31 , 2019. http://saharareporters.com/2019/01/31/nigeriangovernment-approves-n91billion-grazing-reserves. 